\title{
Pluvial Flooding Risk Analysis and the Solutions to Risk Mitigation for Dangyang City in China
}

\author{
Yuhong Li \\ China Academy of Urban Planning \& Design, Beijing 100037, China \\ lidraco@163.com \\ Lian Shi, Jiazhuo Wang, Yingjun Hu, Jin Fan \\ China Academy of Urban Planning \& Design, Beijing 100037, China
}

Received 27 February 2015

Accepted 27 April 2015

\begin{abstract}
This paper introduces Urban Storm Water Drainage and Localized Pluvial Flooding Mitigation Planning of Dangyang City of Hubei Province in China. With the help of ARCGIS、MIKE FLOOD and other software, we found that the two main courses of pluvial flooding in Dangyang city are the flash floods around the city and the insufficient drainage river. What's more, the growth of hardening area and the weakness of storm sewer are two other reasons which increase the risk of pluvial flooding. Then, we gives several solutions for mitigation pluvial flooding risk based on analyzing the cause of pluvial flooding, identifying risk area and assessing the risk of pluvial flooding in Dangyang city. Finally, we proved that the given solutions can achieve good effect according to the simulation results with MIKE URBAN software.
\end{abstract}

Key Words: Drainage and pluvial flooding mitigation planning, Risk assessment, Pipeline survey, Hydraulic modeling

\section{当阳市内涝风险分析及对策研究}

栗玉鸿，石炼，王家卓，胡应均，范锦

(中国城市规划设计研究院，北京 100037，中国)

摘要: 本文以当阳市城区排水防涝规划为例, 借助 ARCGIS 与 MIKE FLOOD 内涝模型等软件分析得出外洪 入城与城区河渠排水功能较弱是当阳市内涝的主要成因, 同时结合遥感影像解译与管网普查工作, 发现下 垫面硬化增加与不完善的管网系统加重了内涝的危害。在内涝成因分析、风险区识别与评估的基础上，提 出高水高排、完善渠道功能、优化管网与加强源头控制的相应对策，并进行规划措施模拟，取得了较好的 效果。

关键词：排水防涝；风险评估；管线勘测；内涝模型

\section{1. 前言}

国家防总历年统计资料显示，近年来全国县级以上 城市洪涝受淹数量总体成上升趋势, 2013 年达到 234 座 $^{[1]}$, 如图 1-A所示。根据住房和城乡建设部 2010 年对 351 个设市城市内涝调查显示, 2008 年以 来, $62 \%$ 的城市发生过内涝, 其中 $74.6 \%$ 的城市最大 积水深度达到 $50 \mathrm{~cm}$ 以上 ${ }^{[2]}$ 。全国内涝频发, 且积水
深度大, 时间长, 已经严重危及到城市安全。如 2010 年 07 月 15 日暴雨导致当阳城区环城南路等地区最 大积水深度达 $1 \mathrm{~m}$ 以上, 当阳近年内涝情况见图 1-B。

城市内涝发生受到地形、河流、城市用地类型 等多方面因素影响, 传统排水规划以管网设计为主, 系统性不足。另一方面, 推理公式法计算的雨水设 计流量与实际降雨过程有一定差距, 适用范围小, 面对城市不断增大的汇水面积, 设计精度会逐渐降 


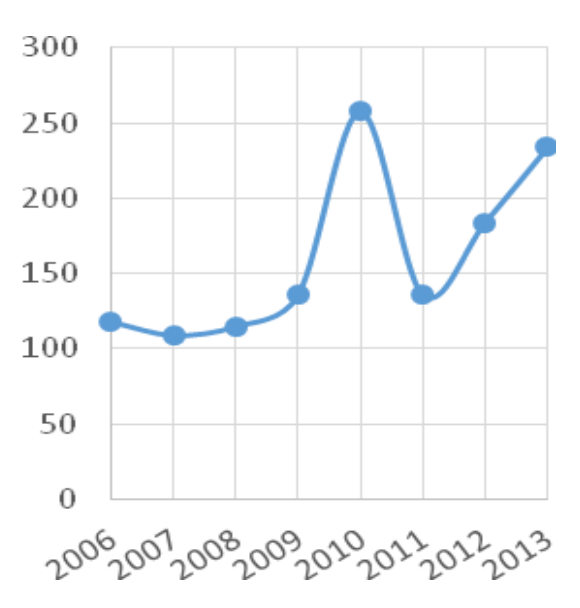

A. 县级以上城市洪涝受淹数量

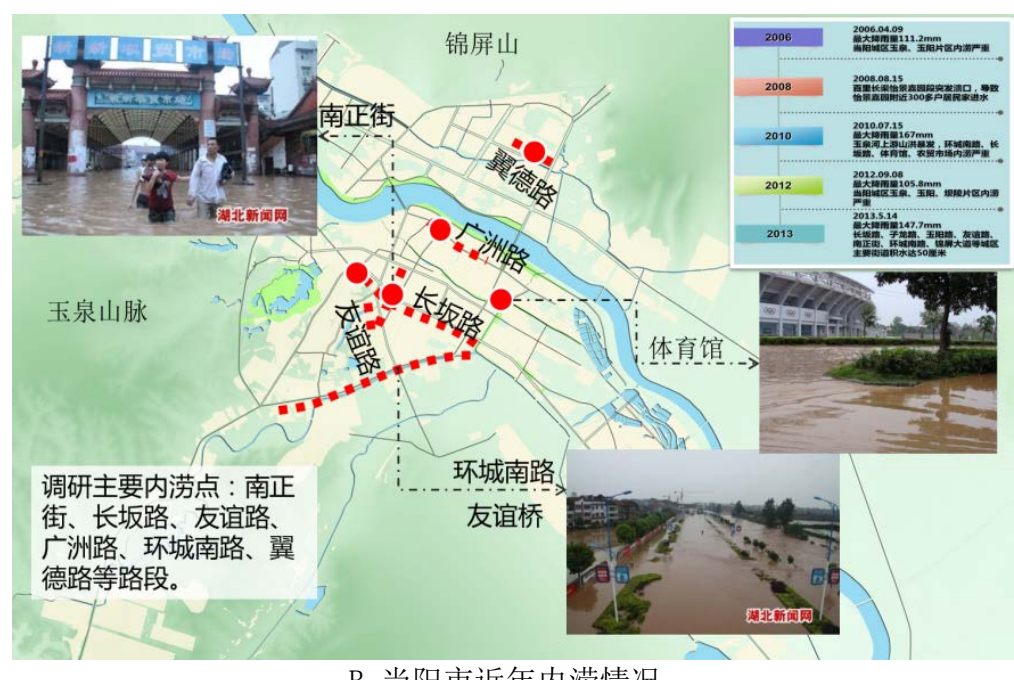

B. 当阳市近年内涝情况

\section{图 1. 全国与当阳市内港现状}

低, 削弱了工程可靠性 ${ }^{[3]}$ 。因此, 通过综合分析内 涝的成因，有针对性的进行河流整治、用地调整、 坚向设计、管渠维护建设等措施, 整体提高城市应 对暴雨的能力成为内涝防治规划的重点。本次规划 摈弃了重点进行管网设计的思路, 在同步开展管线 勘测工作的基础上, 通过内涝模型构建, 城市地形 与下垫面的解析, 综合分析了当阳市城市内涝的主 要成因, 进行风险识别与评估, 有针对性的提出解 决思路与对策，从而有效指导本次规划的水系、管 网以及用地与坚向等方面系统方案的构建, 并通过 软件对规划后效果进行了初步模拟验证。

\section{2. 城市概况}

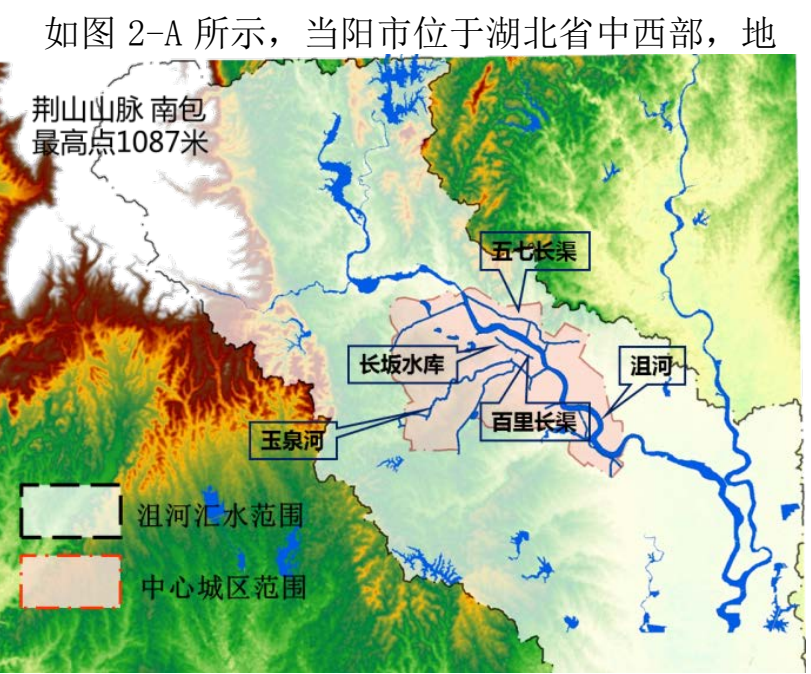

A. 当阳市城区汇水区
处大巴山余脉，荆山山脉以南，鄂西山地向江汉平 原过渡地带, 沮河由西北向东南穿过。当阳市中心 城区位于沮河两岸的河谷盆地地区, 三面环山, 城 区坡度变化较大，西北一东南平均坡降可达 $4.7 \%$ 。

中心城区主要水系有沮河、玉泉河、百里长渠、 五七长渠、长坂水库泄洪道等, 具体分布见图 2-B。 沮河为区域性河流, 在当阳全境河道长 $62 \mathrm{~km}$, 一般 水面宽 $250 \mathrm{~m}$, 沮河城区段上游接纳长坂水库泄洪道 排水, 长坂水库位于城区西侧, 承担着城市西部山 区重要的山洪调蓄功能; 中部有支流玉泉河, 其为 自然雨水冲沟, 发源于当阳市西南玉泉山内。南北 两侧分别有百里长渠和五七长渠两条灌溉渠道, 水 源来自沮河, 百里长渠兼有发电功能, 五七长渠同 时还接纳部分城市生活污水, 以及北部山区来水。

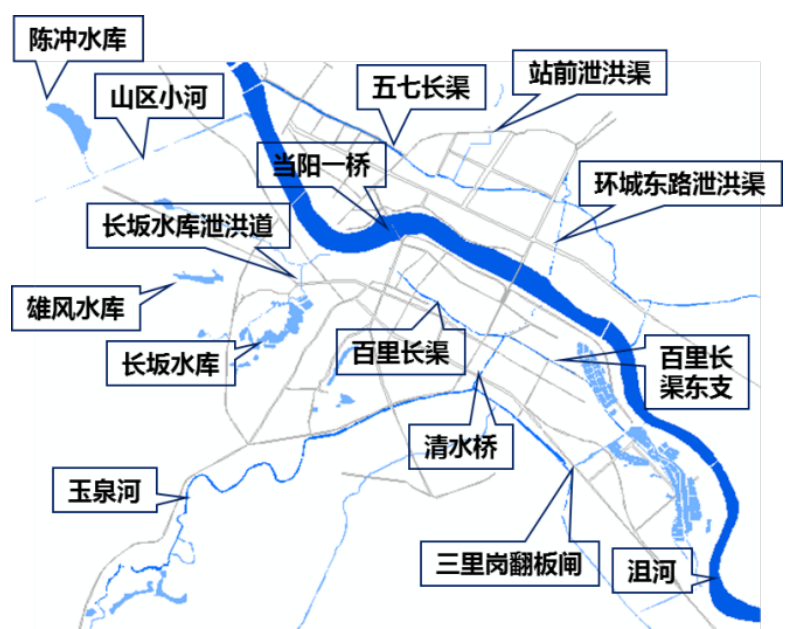

B. 当阳市区水系分布

图 2. 当阳市城市水系与汇水区示意图 


\section{3. 内港风险评估}

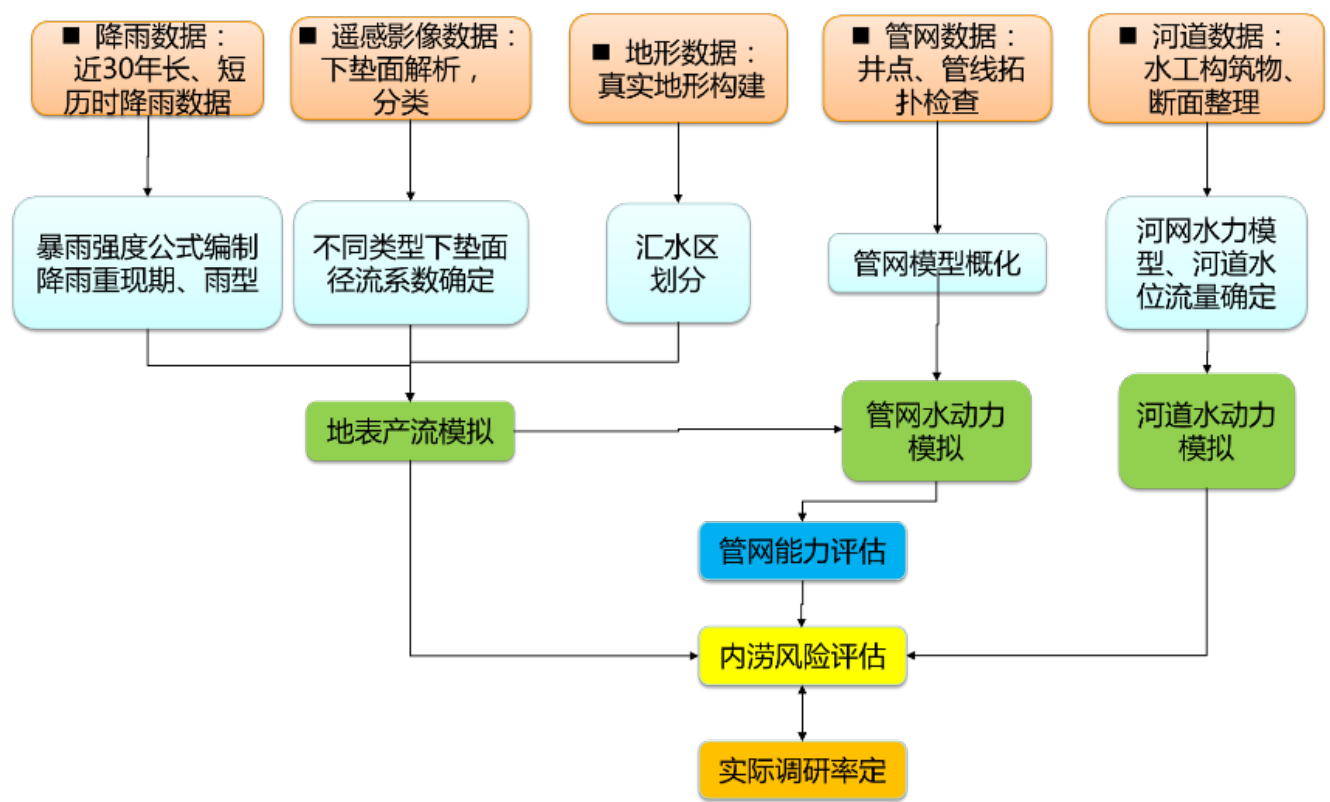

A. 内涝风险评估内容
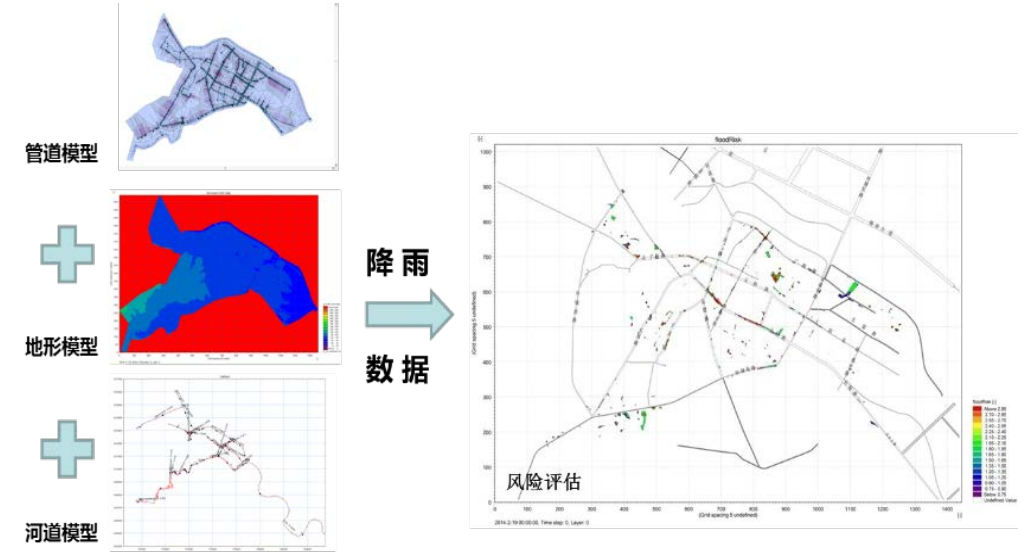

B.模型构建流程

图 3. 当阳市内涝评估流程

按照住建部《排水 (雨水) 防涝综合规划编制 大纲》要求, 基于雨水水力模型的评估是防涝规划 的主要技术手段之一。本次规划通过对地形、下垫 面、河道、管网等资料分析, 结合历史调查与模型 评估, 综合分析当阳市中心城区内涝风险的程度与 分布区域, 具体流程见图 3。

\section{1 河谷地形导致城市整体河洪、山洪风险较高}

地形的起伏变化直接影响着地表径流的汇水面 积、产汇流量与产汇流速度。借助ARCGIS等工具, 将现状地形高程点进行差值, 模拟真实地形, 通过 高程、坡度、盆域分析等一系列水文分析手段 ${ }^{[4]}$ 可 迅速判断城市的主要低洼地段、洪水淹没区与易积
水范围等, 识别内涝风险范围。同时通过建筑物拔 高, 下穿立交高程调整等手段, 构建更精细化的城 市二维地表模型, 进一步保证后期内涝模拟中城市 径流的真实性。具体流程见图 4。

通过地形分析发现, 当阳市中心城区地处山区 河谷盆地, 沮河上游汇流面积达 $3910 \mathrm{~km}^{2}$, 结合历史 洪水位情况, 区域洪水过境会明显抬高沮河水位, 形成顶托甚至倒灌，制约城区排水。中心城区沮河 两岸直接排入沮河区域面积约 967ha, 占现状建设 用地的 $40 \%$ 以上，河道水位对城区排水影响的范围 大，洪水期时内涝风险较高。 


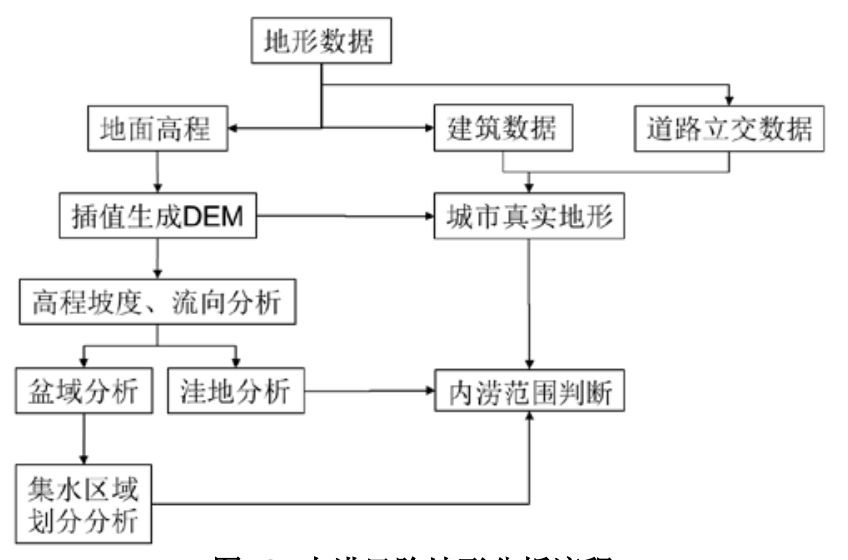

图 4. 内涝风险地形分析流程
根据图 5 所示，当阳中心城区周边山体众多， 山体汇流面积约 $279 \mathrm{~km}^{2}$, 是中心城区规划建设用地 的 5 倍, 且地形坡度多在 $3^{\circ}$ 以上。有研究表明, 地形坡度从 $3^{\circ}$ 增加到 $5^{\circ}$, 地表径流量可增加 $14.4 \%$, 汇流时间缩短 $20.0 \%{ }^{[5]}$ 。山地汇水面积大, 坡度陡，山洪入城流量大，汇流时间短，使得城市 河渠、管网无法承受，成为当阳市城区内涝的主要 原因之一。以玉泉河为例, 其上游汇流面积为 $86.2 \mathrm{~km}^{2}, 2010$ 年 7.25 暴雨河道最大山洪流量为 $300 \mathrm{~m}^{3} / \mathrm{s}$, 玉泉河友谊桥下游漫堤, 漫堤水位 $63.4 \mathrm{~m}$, 高于周边地面 $1 \mathrm{~m}$ 以上, 造成环城南路、环城东路、 长坂路东段等地受灾严重。

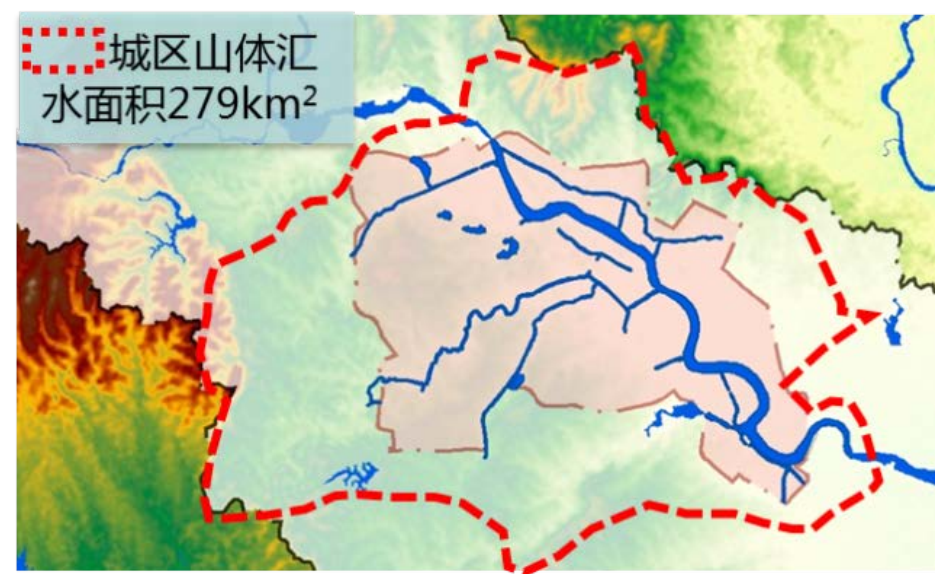

$A$ 城区山体汇水面积

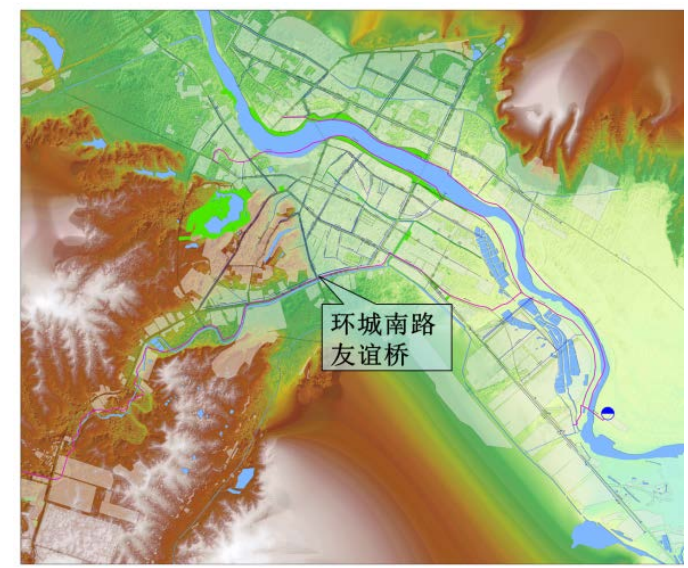

$B$ 中心城区地形

图 5. 当阳市中心城区山体汇水范围与地形图

\section{2 河渠承担排水功能较弱, 两岸内涝风险大}

城市河渠湖泊是雨水径流的最终出路, 河道断 面缩减、排水能力降低, 水库调蓄容积不足是当阳 市内涝发生的又一重要原因, 河渠两岸成为主要内 涝区域之一。

如城区内百里长渠和五七长渠原为引水渠道, 设计之初较少考虑城市排水需求。其中百里长渠以 梯形断面为主, 上口宽约 10-15m, 设计最大过水流 量为 $15 \mathrm{~m} / \mathrm{s}$ 。在老城区范围内, 百里长渠仅承担约 29ha 用地排水, 同时由于其渠道较长, 水位变化慢, 为适应灌溉、发电的需要, 降雨前极少提前降低渠 道水位, 排水能力受限, 雨水管道接入困难。且其 东支目前处于废弃状态, 分流功能未得到利用。

五七长渠城区段长 $8.4 \mathrm{~km}$, 设计渠底宽 $6.0 \mathrm{~m}$, 水深 $2.5 \mathrm{~m}$, 坡度 $1 / 1200$, 局部区段设计过流能力仅 为 $5 \mathrm{~m}^{3} / \mathrm{s}$ 。但五七长渠承担着部分污水与城区北部山 地丘陵地区汇水的排放, 其北侧山体汇流接近 $20 \mathrm{~km}^{2}$, 原有灌溉设计流量较小, 山洪易漫溢至周边道路, 加之山洪入渠后抬高水位, 影响北侧管道排水, 较 易导致渠道北侧发生内涝, 五七长渠北侧翼德路一
带现状降雨时常有积水发生。两条渠道现状集水区 域范围见图 6.

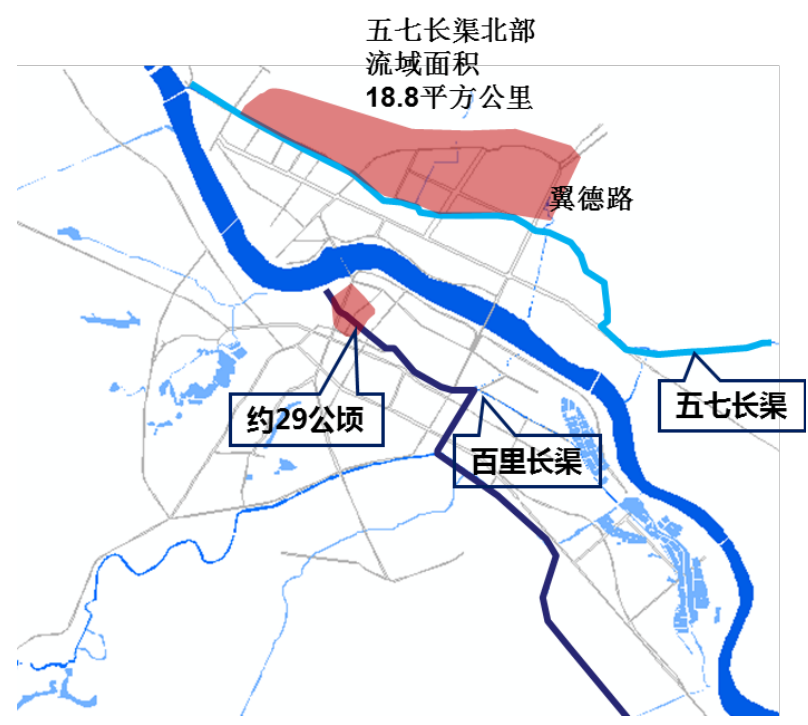

图 6. 当阳市渠道汇水范围 
为此通过河渠水库设计资料查阅, 实地测量等 方式, 采用MIKE 11 构建了当阳市水系水动力模型, 具体形式参见图 3-B。搭建的当阳市水动力数学模 型除了可输出流量、水位这两项最为重要的水文结 果, 还可以输出水量、流速、水面宽度等一系列的 衍生结果 ${ }^{[6]}$, 从而为规划设计提供更加丰富的技术 支持。

\section{3 城市下垫面变化, 内涝区域扩张}

当阳市城市扩张迅速，仅 2007 年至 2010 年, 当阳市中心城区建设用地增加达 954. 65ha。由于山 地丘陵地形条件的限制, 当阳市用地条件紧张, 使 得城区内原有大量的河塘水面被占用, 城市径流系 数不断增大。根据影像图解译初步测算, 现状当阳 玉泉片区城市环路以内绿地面积为 $17 \%$ (含小区绿 地), 水面为 $4 \%$, 建设用地与道路达到 $73 \%$ 以上, 在 未考虑坡度影响的情况下, 加权计算现状综合径流 系数已达到 0.7 以上 (见表 1 ), 处于较高水平 ${ }^{[7]}$ 。 对比图 7 中 2004 年与 2012 年当阳城区影像图能够
看到，现状财政小区位置以及体育场附近原有大量 坑塘水面已经消失, 城市建设下垫面改变十分明显。 硬化面积的增大直接导致城区雨水径流的增大。以 财政小区为例, 坑塘消失后, 其下游长坂路二医院 附近成为当阳市主要的内涝点, 上游来水量大流急, 井盖被冲起情况时有发生。

当阳市部分重要的泄洪通道与调蓄水库也受到 不同程度的侵占, 以坝陵片区站前泄洪通道为例, 其承担着北部大量山洪的排泄, 由于泄洪通道流经 区域改建为厂房, 通道由明渠变为暗涵, 断面尺寸 缩小, 初步测算, 由于断面和坡度的变化, 过流能 力缩减 $75 \%$ 以上。城区西部长坂水库为山区洪水重 要的截留、调蓄水库, 防洪库容 45 万 $\mathrm{m}^{3}$, 由于周边 的开发，水库调蓄空间受到制约，其下游泄洪通道 也存在上盖建筑、断面缩小等情况, 严重影响到水 库的排洪能力, 水库与泄洪道周边低洼地区存在较 大内涝隐患。

表 1. 当阳市老城区下垫面综合径流系数分析

\begin{tabular}{ccccc}
\hline 下垫面类型 & 面积 $\left(\mathrm{km}^{2}\right)$ & 比例 $(\%)$ & 径流系数 & 综合径流系数 \\
\hline 建设用地 & 5.31 & $61.5 \%$ & 0.85 & \\
绿地 & 1.51 & $17.5 \%$ & 0.30 & \\
水系 & 0.33 & $3.8 \%$ & 0.00 & 0.72 \\
裸地 & 0.56 & $6.5 \%$ & 0.50 & \\
道路用地 & 0.92 & $10.2 \%$ & 0.95 & \\
\hline
\end{tabular}

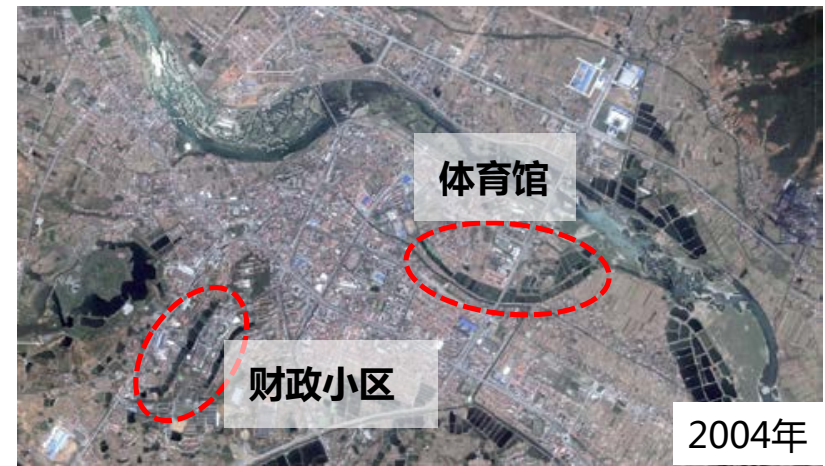

A. 2004 年玉阳玉泉片区影像图

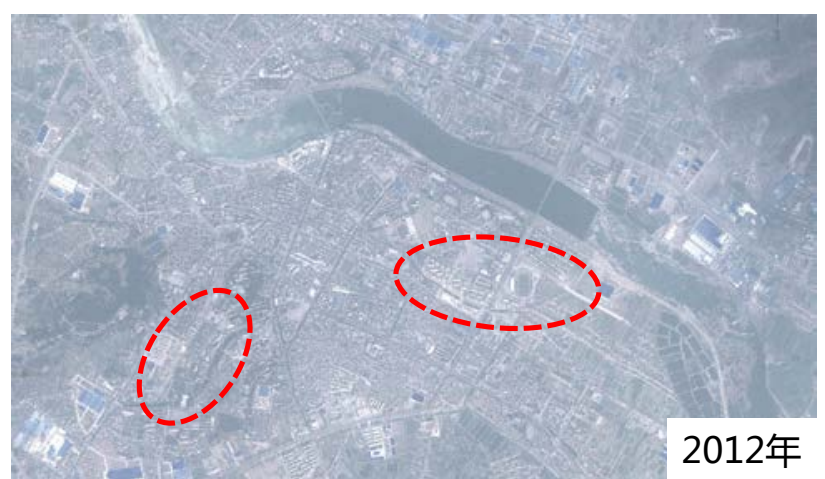

B. 2012 年玉阳玉泉片区影像图

图 7. 当阳市中心城区下垫面变化情况

\section{4 管网系统不完善, 排水能力不足}

当阳市现状合流制管网多数修建年代较久, 管 径较小, 多不足 $1000 \mathrm{~mm}$, 随着城市扩张, 汇水面积 增大, 导致管道设计标准降低。规划同步开展了管 线勘测工作, 是本次防涝项目的一次重要实践。通
过构建图 8 所示管网属性数据库。项目组详细了解 了当阳市排水管网的现状特征，为日后城市地下排 水管网的建设维护工作提供有力的支撑, 也是本次 规划的重要基础数据。 


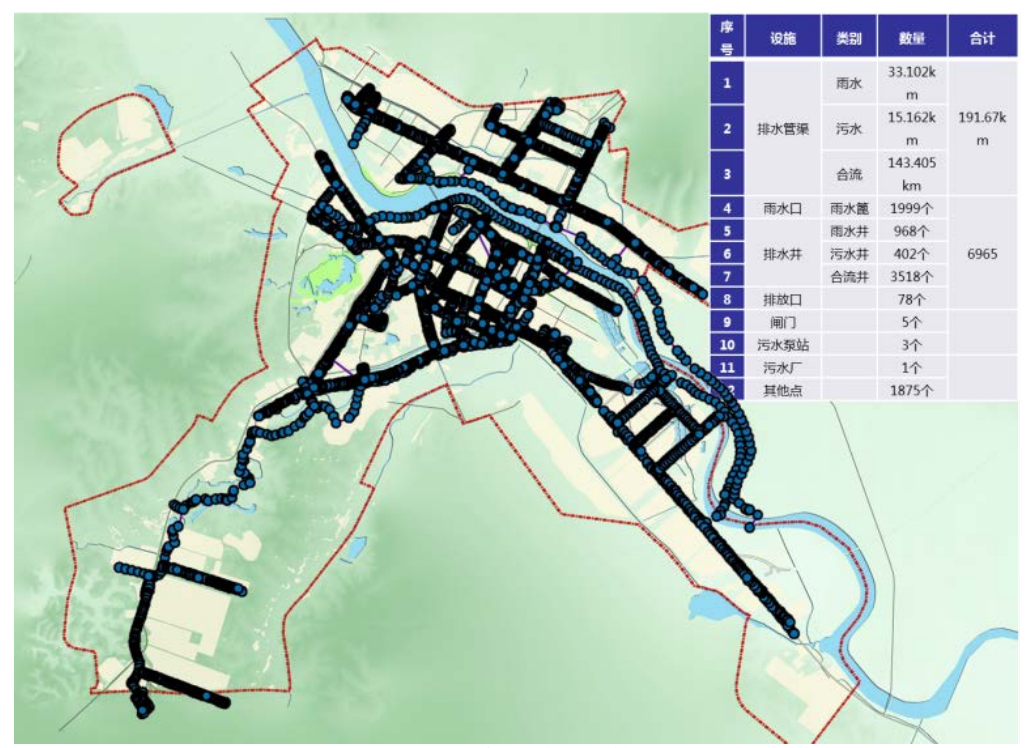

图 8. 当阳管网勘测数据库

结合地形汇水区分析, 下垫面解析以及降雨规 律研究, 采用 MIKE URBAN 管网模拟软件综合评估了 当阳市管网能力, 评估过程见图 9。受到地块开发 建设与管网修建难以同步的影响, 现状锦屏大道西 段、坝陵大道南端等区域下游排水管道未能修通, 导致排水管道下游无出路; 而广洲路等区域, 排水 管网路线曲折, 系统不够顺畅。同时现状管线还存

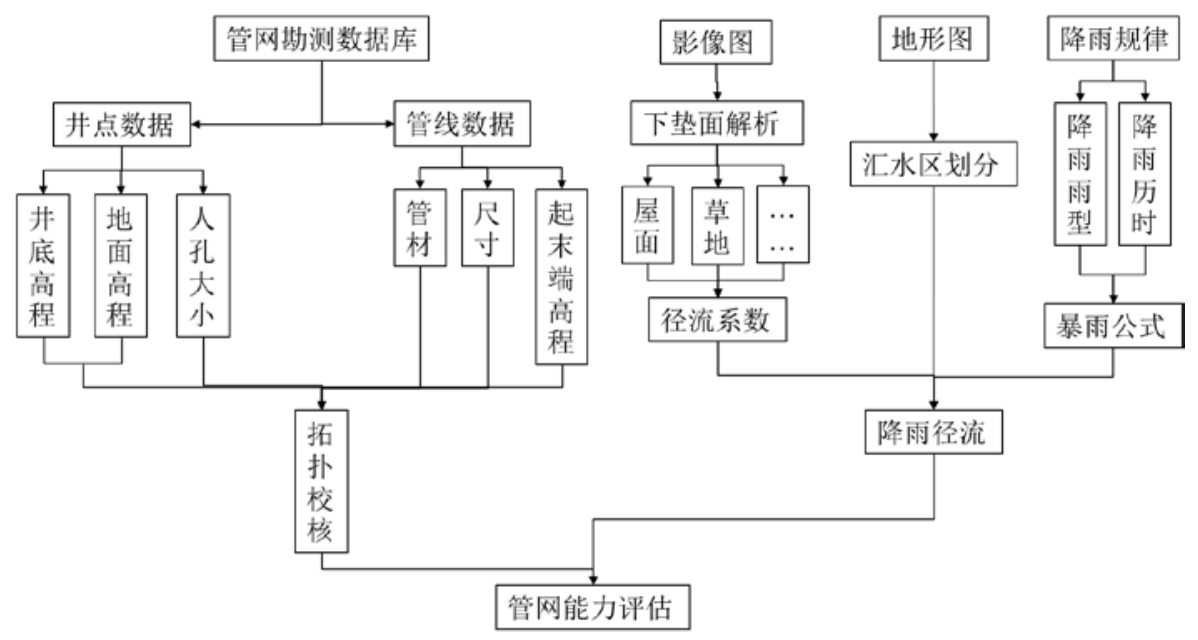

图 9. 当阳市管网能力评估流程

以上这些因素都严重影响了现状管网的排水能 力。根据图 10 显示模型模拟评估结果, 老城区现状 管网超过 63\%的管道不满足 1 年一遇标准, 现状管 网能力较差的道路主要有: 长坂路、太子桥街、广
在一些大管接小管、管道逆坡等情况。加之市民公 共意识不强以及管理不善, 部分道路管道淤积情况 十分严重。另一方面当阳市现状排水体制以截流式 合流制为主，截流管道不足，受河道水质的要求, 合流管网需流经较远距离才能接入现有截流管道, 导致城区排水系统河道排放口少，管道流程长，汇 水分区大，雨水不能快速排入水体。

洲路、子龙路、南正街; 坝陵片区现状管网中超过 $78 \%$ 的管道不满足 1 年一遇标准, 现状管网能力较差 的道路主要有: 锦屏大道、翼德路、花园街南段等。 


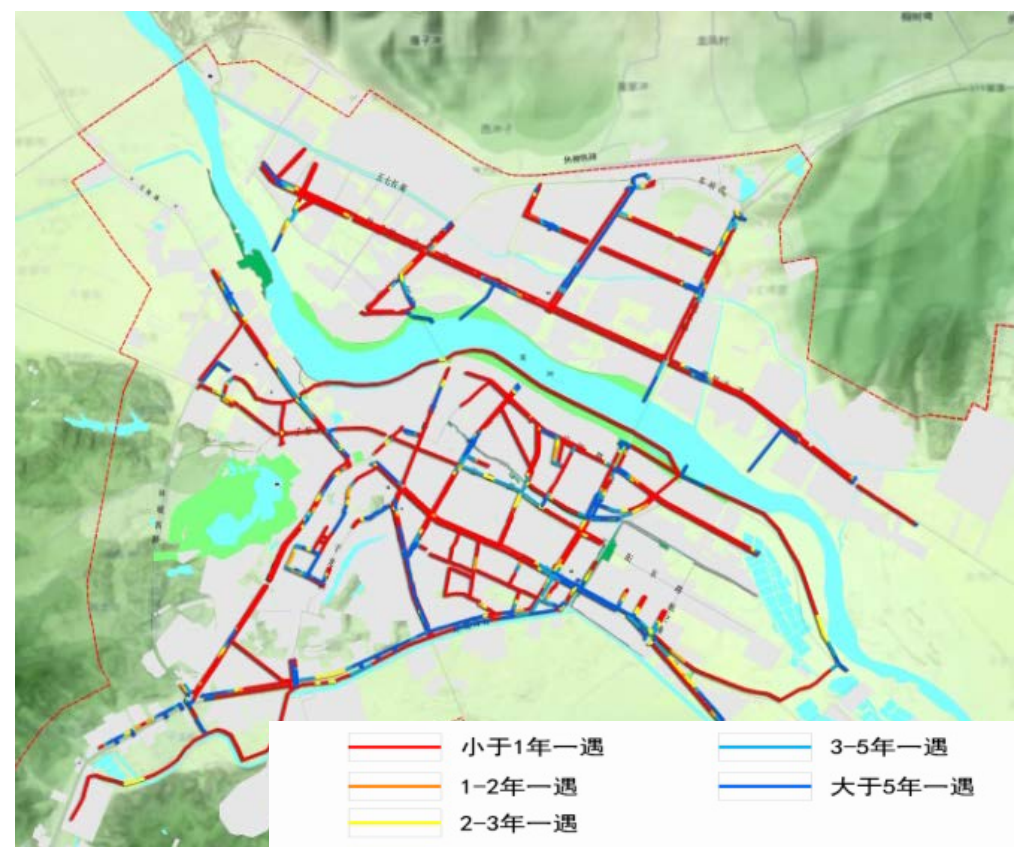

图 10. 当阳管网勘测数据库与管网能力评估

\section{5 内涝风险综合评估}

采用 MIKE FLOOD 软件耦合上述城市二维地表模 型、河道模型以及排水管网模型, 得到城市内涝区 分布情况，进行内涝风险评估。

以 5 年一遇 2 小时降雨作为输入参数进行常规 情况下的内涝风险模拟。根据模拟结果, 采用城市 地表积水时间和积水深度的双因子评估方法, 将内 涝风险总体划分为三类: 内涝低风险区、内涝中风 险区和内涝高风险区。内涝风险划分标准见表 2 。
用 ARCGIS 软件对模型结果进行统计分析, 通过 对每个划分区域内涝淹没时间和淹没深度进行统计, 得出当阳现状城区 5 年一遇 2 小时内涝风险分布图, 分布情况见图 11。内涝风险区域与当阳市历史内涝 情况进行了校核, 一致度较高, 符合实际情况, 同 时模拟结果亦发现了历史数据未提及的区域, 经过 实地调查能够得到验证。据内涝风险区划结果, 统 计不同等级风险区面积如表 3 所示。

表 2. 当阳市内漟风险矩阵表

\begin{tabular}{cccc}
\hline 积水深度 & 0-30时间 & 30-60min & 60-120min \\
\hline $0.15-0.25 \mathrm{~m}$ & 内涝低风险区 & 内涝中风险区 & 内涝中风险区 \\
$0.25-0.5 \mathrm{~m}$ & 内涝中风险区 & 内涝高风险区 & 内涝高风险区 \\
$>0.5 \mathrm{~m}$ & 内涝高风险区 & 内涝高风险区 & 内涝高风险区 \\
\hline
\end{tabular}

表 3. 当阳市现状内涝风险区面积统计表

\begin{tabular}{cccc}
\hline 区域 & 低风险区（ha） & 中风险区（ha） & 高风险区（ha） \\
\hline 玉阳玉泉片区 & 4.88 & 6.29 & 8.15 \\
坝陵片区 & 3.32 & 3.67 & 1.59 \\
\hline
\end{tabular}

从图 11 内涝风险评估示意图中可以看出, 内涝 区域与前述单项风险评估较为一致, 泄洪道缩减地 区、管道堵塞地区、河道两侧以及低洼地区、主干 管网排水能力不足地区、原有集中坑塘水面周边与 下游地区等都存在内涝风险。内涝风险程度受到几
方面原因的综合叠加, 呈现出不同程度的风险等级。 其中, 当阳市主干道长坂路在上游水面缩小情况下, 受到山洪来水冲击, 加之管道能力不足, 管道汇水 区大，流程长，是内涝风险最高的地区，为本次规 划重点解决的区域之一。 


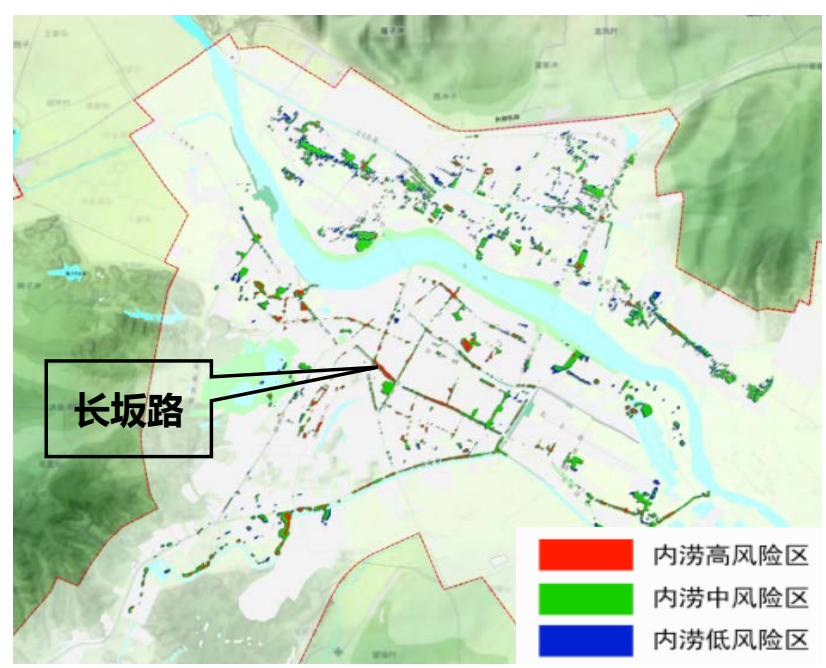

图 11. 当阳市内涝风险评估示意图

\section{4. 解决对策}

超过下垫面滞蓄调节能力的雨水形成地表径流， 径流通过合理构建的雨水管渠系统收集, 最终进入 城市内河、冲沟、重要的行泄通道、或水库湖泊等 调蓄水面。因此以雨水径流控制为主的源头控制体 系, 以雨水管渠系统为主的收集排放体系, 以河道 沟渠和湖泊水面为主的雨水受纳体系, 是防涝规划 重点解决的三个方面 ${ }^{[8]}$ 。这三方面的措施相互关联, 构成了完整的系统方案。以排水管网为例, 其排水 口设置、竖向设计, 受河渠水面的水位、流量的制 约; 径流系数的选取由下垫面低影响开发等径流控 制措施决定; 同时超出管网排水能力的雨水也需要 合理布置径流的调节调蓄措施。本次规划方案从三 个方面入手, 协调三者之间关系, 以期达到较优的 内涝防治能力。

根据当阳市内涝风险评估可知, 降低外部山洪 对城市的影响, 完善现有渠道功能, 缩小排水分区 是当阳市内涝防治的重要措施。

\section{1 疏导外部洪水, 完善渠道功能}

当阳市水系整治体系总体思路为外部截留, 中 部连通, 重点整治。规划城区外部新增截洪沟, 中 部河渠连通, 重点整治现有沟渠河道, 并对河渠走 向、断面进行了较为详细计算设计, 提高河渠整体 过流能力, 具体河渠与水工构筑物整治建设要求、 尺寸、控制水位等参见图 12 。

针对城区山洪风险较高的特点, 坚持高水高排 原则, 构建完善的山洪截洪体系, 将城市西部、北
部山洪快速导入周边水体, 降低山洪对城市排水系 统的影响。玉阳玉泉片区西侧近山地区, 已经建设 的长坂水库等承担着重要的山洪调蓄作用, 应避免 对水库的侵占, 并严格控制各个水库的水位, 保障 调蓄, 同时重点恢复整治水库现有泄洪道。对于北 部坝陵片区, 由于缺少水库调蓄, 且沟渠较少, 重 点于环山路、车站路等沿山道路建设截洪泄洪沟, 将山洪快速导入五七长渠, 避免对城区管网造成较 大压力, 有效降低内涝风险。

城市中部着重恢复连通现有百里长渠东支, 使 得百里长渠可尽早排入沮河, 减轻下游发电水位对 百里长渠排水能力的影响, 提高老城区百里长渠两 侧排水能力。远期建议取消下游发电功能, 进一步 提高百里长渠对水位的调控能力。为避免玉泉河山 洪顶托百里长渠水位, 造成倒灌, 除增大百里长渠 下游三里岗翻版闸的排水能力与调控精度外, 规划 于玉泉河与百里长渠交汇处设置闸门一座, 当玉泉 河水位达到 $61 \mathrm{~m}$ 时, 关闭闸门, 阻隔山洪入城。

合理取定沮河、玉泉河等受纳水体设计水位, 通过断面整治, 扩大过流能力的基础上, 为管网、 原站以及场地坚向规划提供设计条件, 保证雨水能 够顺利排入河渠。城区内部玉泉河为设计重点, 其 汇水区紧邻城区, 采用常水位设计, 以 20 年一遇洪 水位校核。城区北部五七长渠受山洪影响较大, 采 用常水位设计, 以 20 年一遇洪水位校核。而百里长 渠可人工控制水位, 无外水汇入, 采用常水位进行 设计。 


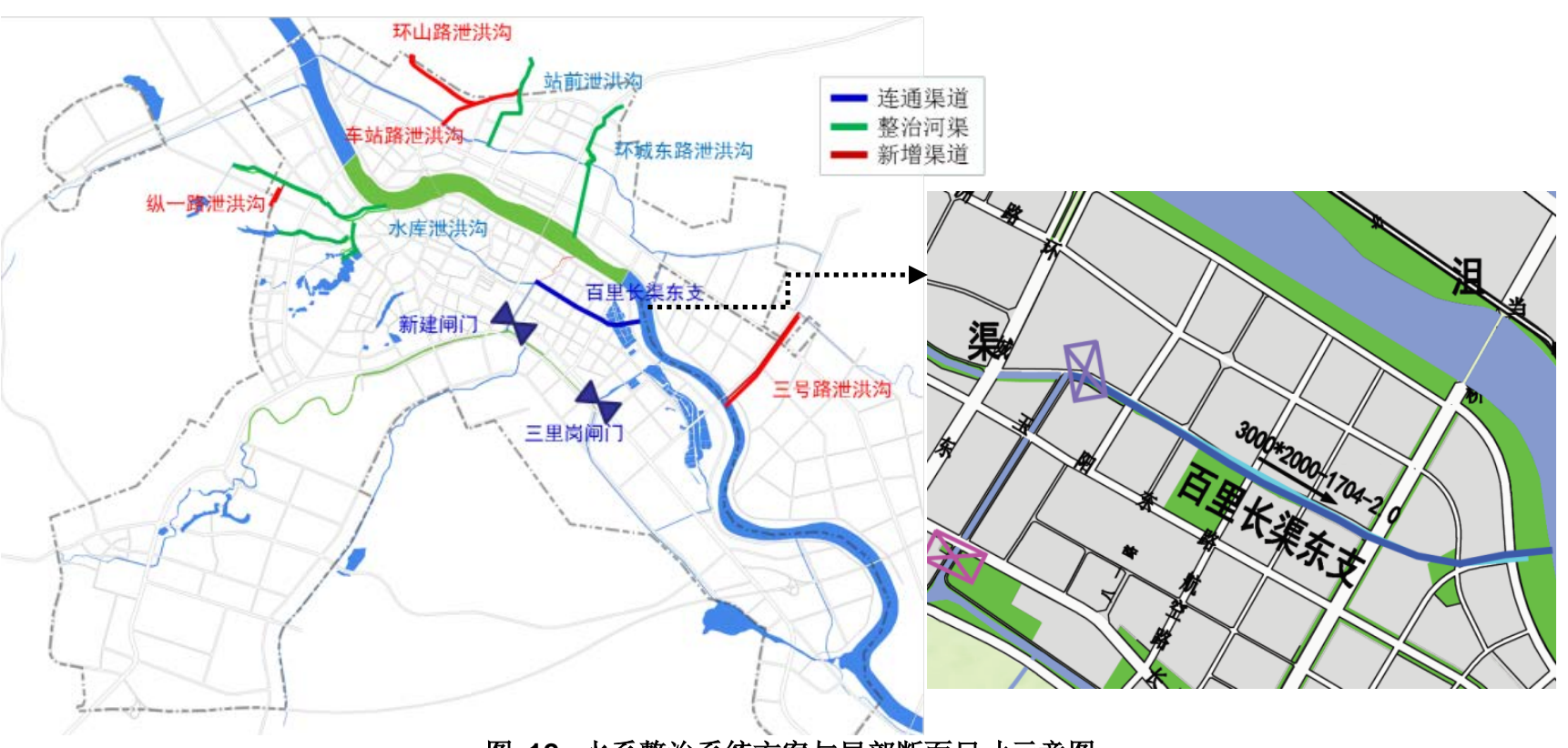

图 12. 水系整治系统方案与局部断面尺寸示意图

\section{2 优化管渠标准, 缩小排水分区}

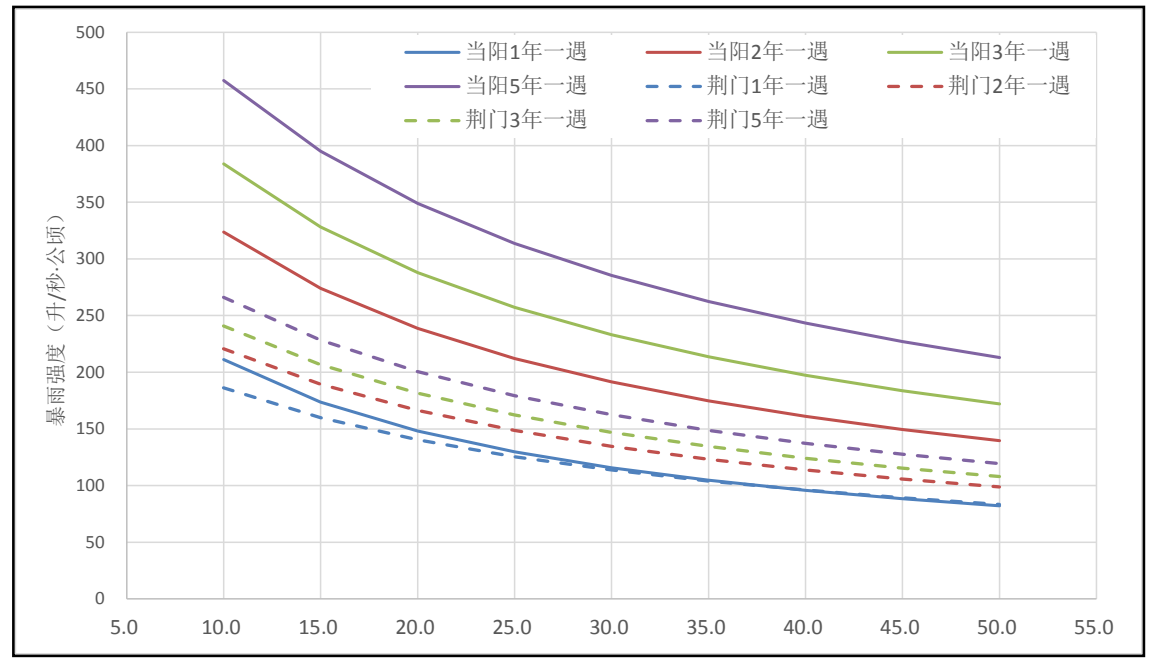

图 13. 当阳与荆门暴雨强度公式对比

管渠设计标准直接关系到城市雨水排水设施建 设的合理性和运行的安全性, 根据《室外排水设计 规范》要求, 当阳市排水管网应达到 2-3 年一遇标 准, 重要地区达到 3-5 年一遇。管渠主干系统的排 水能力影响到整个汇水区的排水效果, 应重点保证 主干管网设计标准达标。确定玉阳片区、玉泉片区、 坝陵片区新改建主干管设计重现期不低于 3 年一遇, 其他地区新建雨水管渠设计重现期不低于 2 年一遇。 为保证设计的精确性, 通过对当阳市近 30 年降雨资 料进行分析, 本次规划编制了当阳市暴雨强度公式 [9]。
如图 13 显示, 对比之前采用的荆门市暴雨强度 公式发现，在 1 年一遇设计重现期条件下，两地暴 雨强度公式差异不大, 引用荆门市暴雨强度公式用 于设计符合当阳的实际情况。但若采用 2 年以上设 计重现期, 当阳暴雨强度公式设计雨量远大于荆门 公式。以 3 年一遇为例, 同等降雨历时当阳暴雨强 度公式计算雨量增加约 60\%, 荆门公式已不适合现 有设计标准, 雨水管渠设计需按新编制的当阳市暴 雨强度公式进行计算, 并利用 MIKE URBAN 软件进行 设计校核。

为解决当阳市老城区排水分区过大的问题，规 
划近期对城区下游主干管逐步进行雨污分流改造, 使得雨水能够尽快排入河渠, 同时重点完善现有截 流式合流制体系, 避免在上游管道分流不彻底的情 况下造成混接污水直排入河道的风险。未来根据道 路改造计划, 逐步推进老城区的分流改造, 对于新 建地区, 严格执行雨污分流建设。依据地形地势、
受纳水体等情况，当阳市共划分一级排水分区 16 个（图 14），每个分区内又结合现状管网走向，未 来开发建设时序等，进一步细化雨水分区，优化雨 水排除路径, 共分为 76 个排水子分区, 有效提高雨 水系统排水效率。

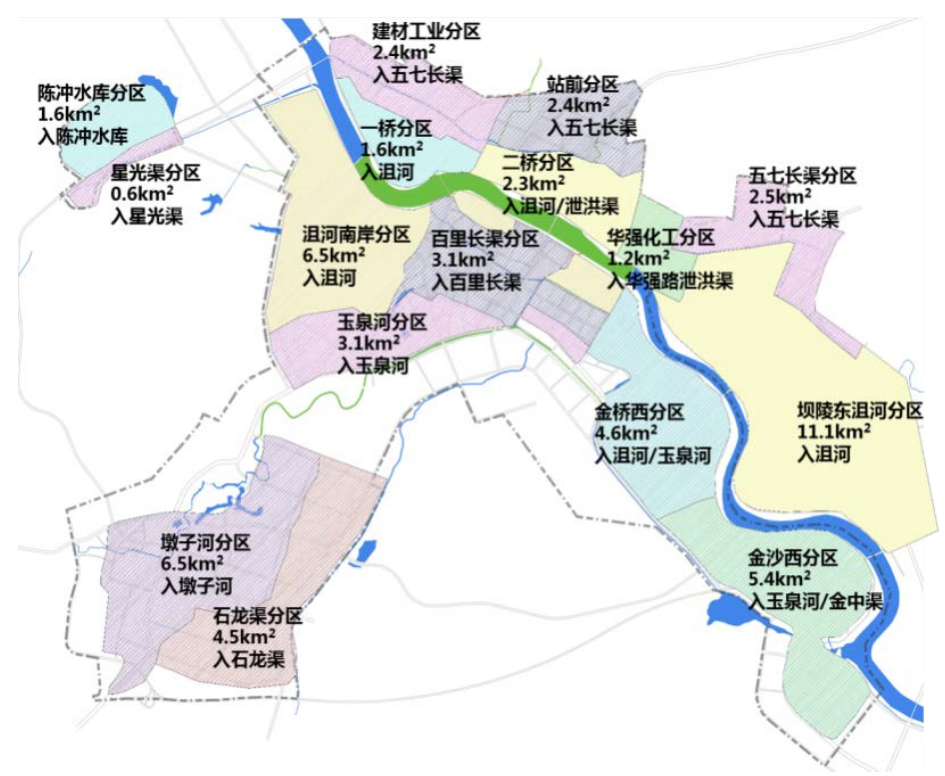

图 14. 当阳市排水管网一级分区图

\section{3 推广低影响开发理念, 应对超标降雨}

积极推动低影响开发理念, 能有效提高当阳市 雨水整体调蓄能力。当阳市现状绿地与广场用地为 114. $23 \mathrm{ha}$, 仅占城市建设用地的 $4.94 \%$, 雨水滞蓄 能力差。规划要求按照总规绿地系统规划, 完善城 市绿地系统的基础上, 通过下凹式绿地改造、透水 铺装等方式, 促进雨水下渗, 减小综合径流系数。 对于新建地区, 推进小区层面的雨水系统设计, 通 过屋顶花园、下凹式绿地、植草沟、雨水花园、雨 水渗坑等多种方式, 加强雨水在小区层面的源头控 制。

规划木店、坝陵、金桥等工业园区低影响开发 面积占新开发面积 $10 \%$ 以上, 鼓励企业雨水回用。 玉阳玉泉片区应在城市更新改造过程中提高透水铺
装比例，人行道全部完成透水铺装改造，新建小区 与公园绿地中下凹绿地占绿地 $40 \%$ 以上, 每 1 万 $\mathrm{m}^{2}$ 硬化需配建 $300-500 \mathrm{~m}^{3}$ 雨水利用设施。加强道路绿 化, 道路红线宽度 $50 \mathrm{~m}$ 以上的道路, 绿地率大于 $30 \%$; 道路红线宽度 40-50m 的道路，绿地率大于 $25 \%$; 道 路红线宽度小于 $40 \mathrm{~m}$ 的道路，绿地率大于 $20 \%$ 。

对于超标降雨, 加大雨水调节力度, 规划于财 政小区下游, 当阳一中操场等地建设局部雨水调蓄 设施, 缓解周边场地与管网压力。规划玉泉河中游、 下游, 长版水库泄洪道下游等区域结合周边绿地、 坑塘构建区域雨水调蓄湿地, 有效调节河渠水位水 量, 提高城市整体排涝系统的运行安全。低影响开 发设施布置与规模见图 15 。 


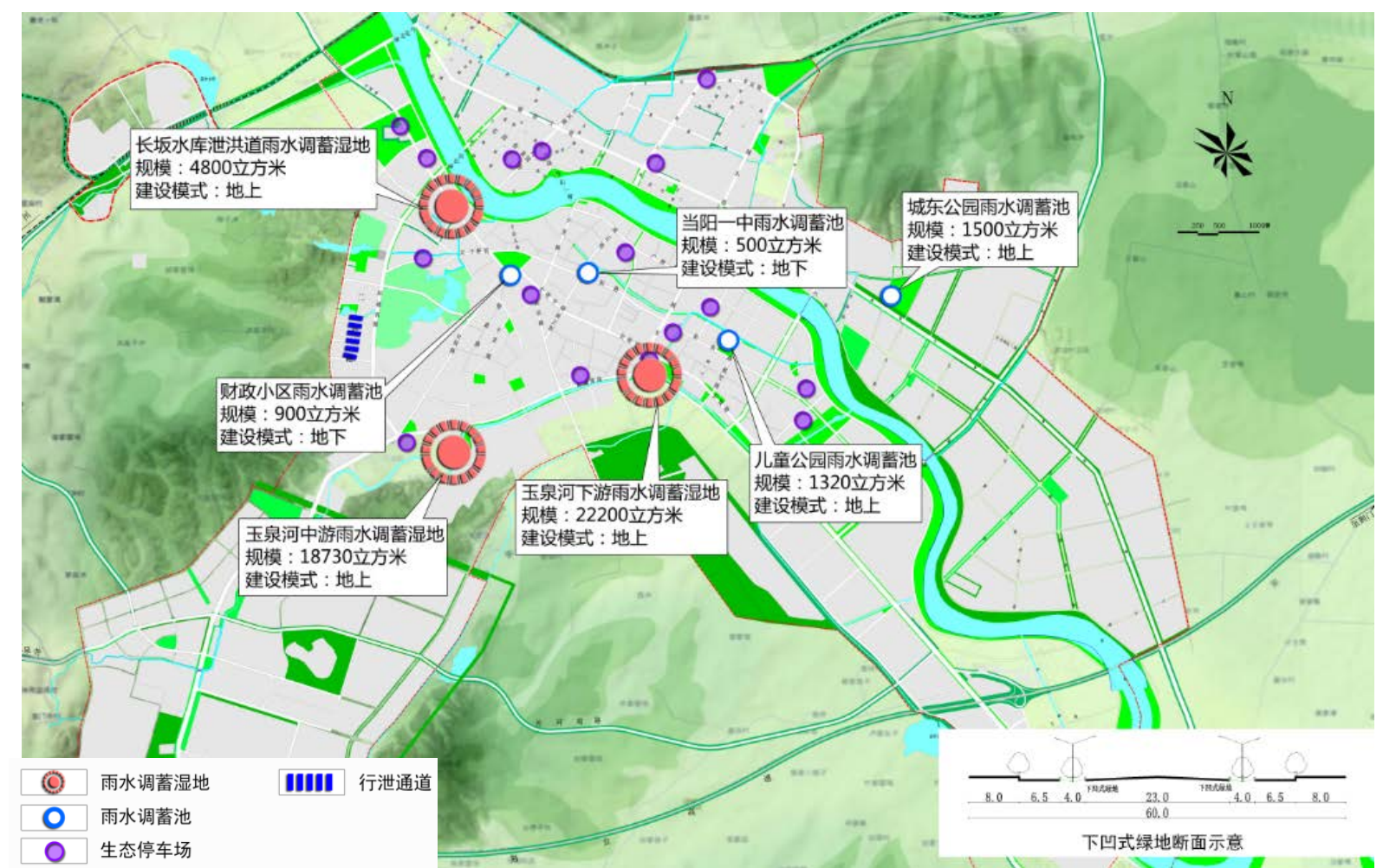

图 15. 当阳市低影响开发与调蓄设施布置示意图

\section{5. 近期规划效果评估}

当阳市排涝规划综合采用了河道水系措施、排 水管网措施、以及径流控制与调节措施三方面内容, 通过三方面措施有机协调, 能够取得较好的规划效 果。

以玉阳玉泉片区近期建设改造内容为例, 通过 重点恢复整治百里长渠东支, 提高百里长渠排泄能
力; 新建清水桥闸门, 改造三里岗翻板闸, 阻隔玉 泉河山洪入城、并提高玉泉河排泄能力; 建设财政 小区调蓄池，提高小区上游坡面雨水调节能力; 改 造长坂路、南正街、广洲路等主要干管系统，提高 管网设计标准等一系列措施，能够有效减少片区内 内涝高风险区域。具体建设内容布置见图 16.

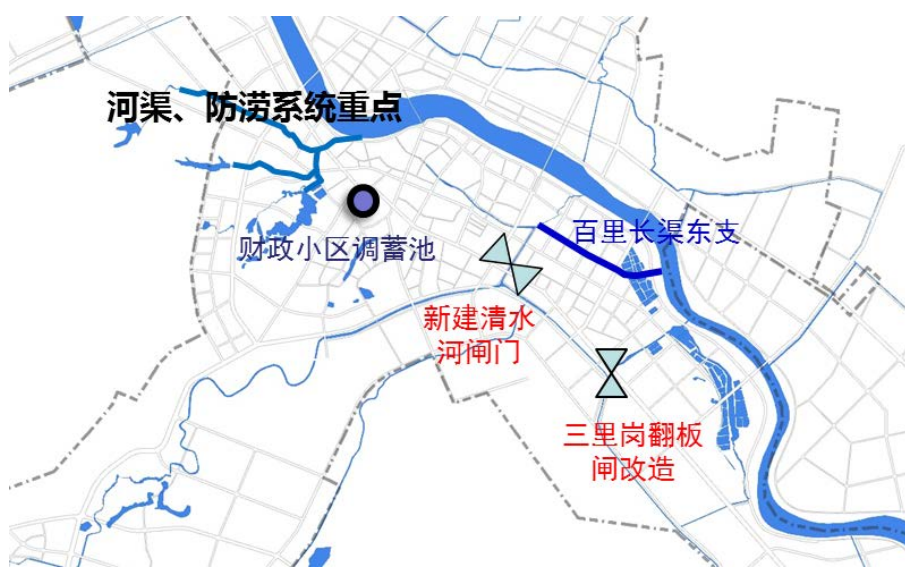

A. 水系、防涝设施近期重点建设内容

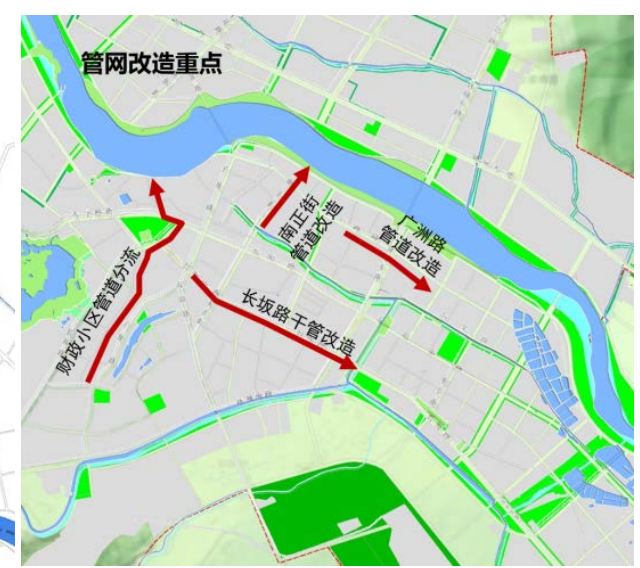

B. 管网近期重点建设内容

图 16. 玉阳玉泉片区近期改造内容

采用 5 年一遇降雨模拟可知, 仅通过以上近期 工程, 片区内涝风险区域整体下降 $25.83 \%$, 高、中 
风险区下降明显, 部分转变为低风险区域。其中内 涝高风险区域减少 $72.64 \%$, 中风险区域减少 $40.22 \%$, 低风险区域增加 70.90\%, 具体变化情况见表 4 与图
17。可以预见, 若未来规划措施全部实施, 内涝风 险区域将进一步减少。

表 4. 玉阳玉泉片区近期改造效果评估

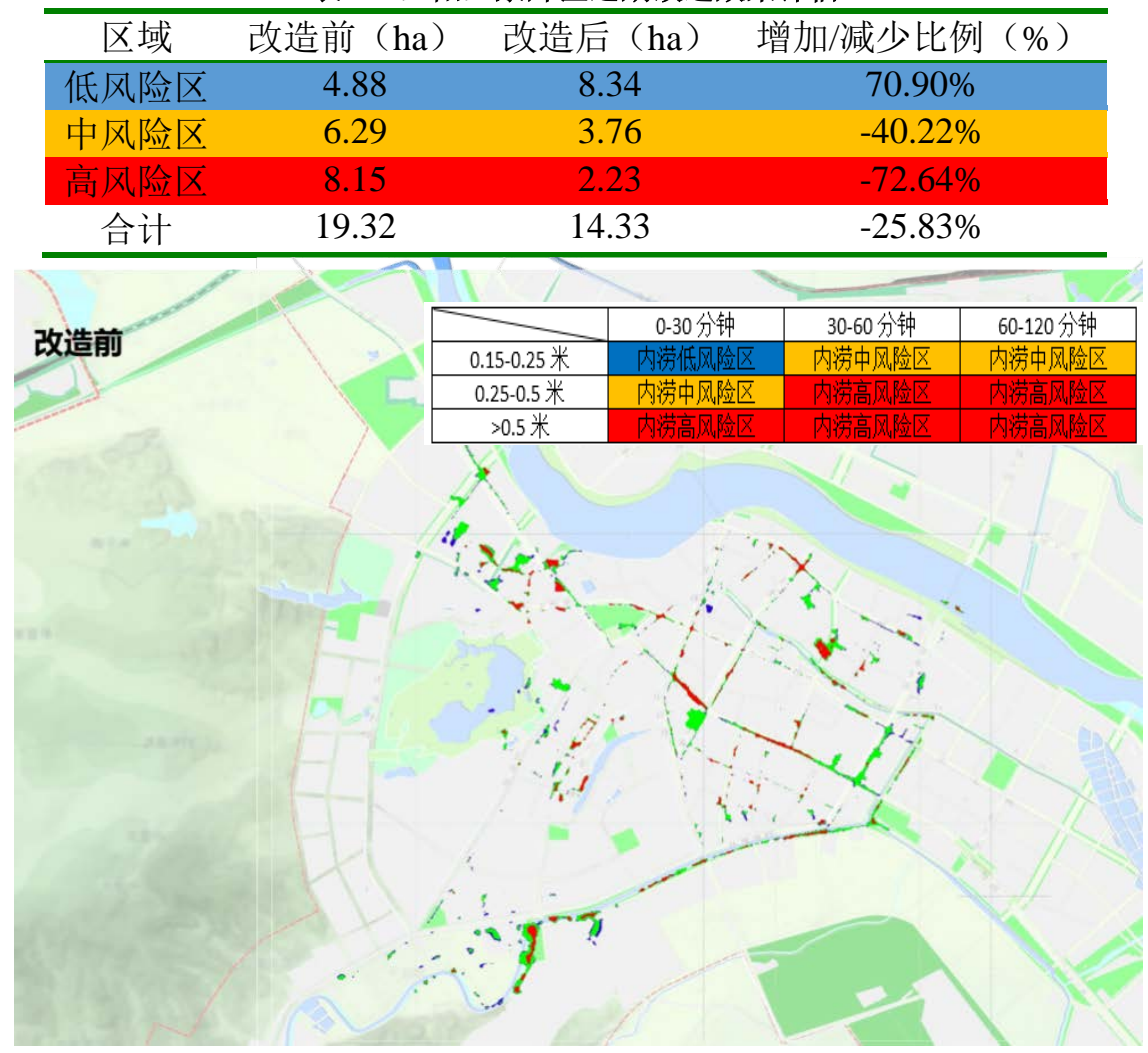

A. 玉阳玉泉片区改造前内涝风险分布

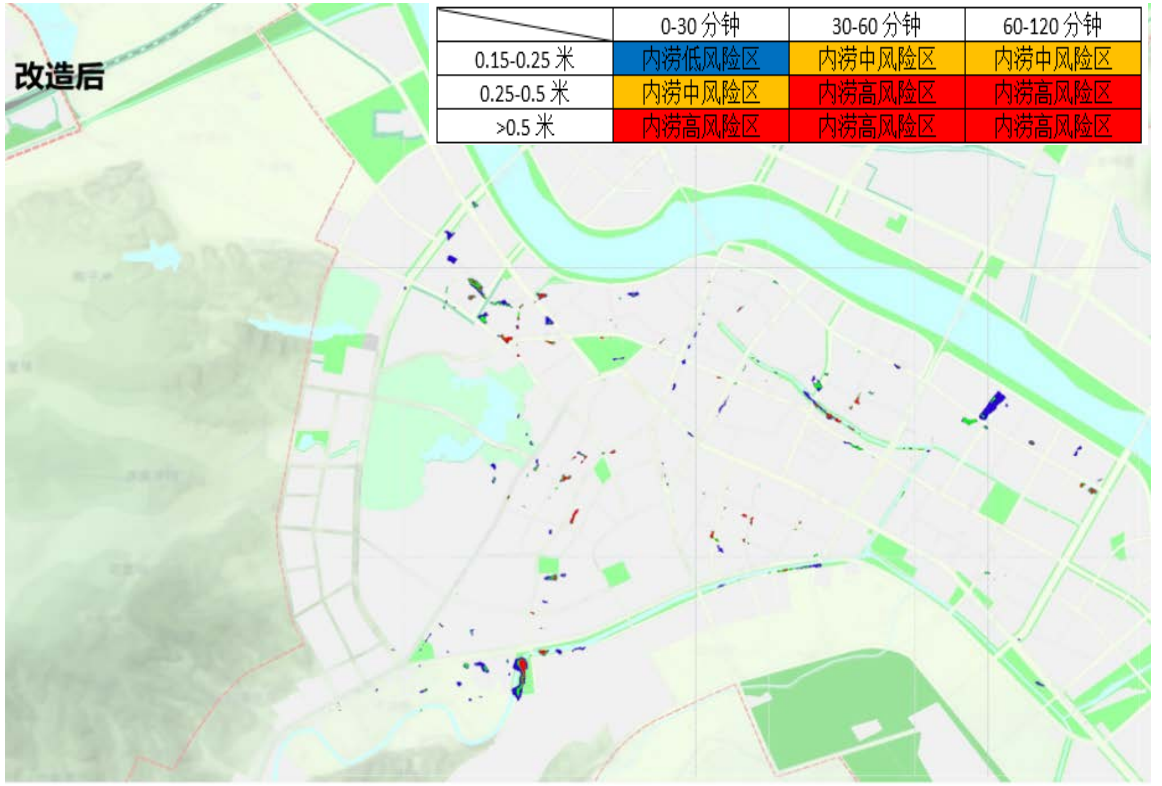

B. 玉阳玉泉片区改造后内涝风险模拟分布

图 17. 玉阳玉泉片区近期改造效果对比图 


\section{6. 结论}

当阳市城市内涝有着典型河谷盆地地区的特征, 外部洪水, 尤其是山洪对城市径流的影响较大, 内 涝防治的首要重点是阻隔外部洪水入城, 减轻城市 内部管网、河渠的压力。

其次针对当阳市引水渠道承担排水功能较弱以 及城区管网分区过大的现状, 有针对性的进行水系 连通与水工构筑物的建设, 并重点改造主干管网, 细化排水分区，有效提高了城区的排水能力。

最后河谷盆地用地紧张的状况造成城市对河塘 水渠的过度侵占, 排涝规划需要重点识别需要保留、 新增的水系水面, 完善水系的排涝功能。本次规划 结合水系、管网以及低影响开发设施的建设, 对城 市用地布局和坚向设计也有相应较为详细的要求, 需要在城市总规与各类专项规划中进行落实。

\section{参考文献:}

1. 国家防汛抗旱总指挥部办公室. 关于 2006 2013 年防汛抗旱工作的报告[EB/OL]. http://fxkh.mwr. gov.cn/

The office of State Flood Control and Drought Relief Headquarters. Flood Control and Drought Relief Work Report 2006 2013[EB/OL]. http://f xkh.mwr.gov.cn/

2. 王家卓, 谢映霞. 中国内涝灾害原因浅析 [J/OL]. 城 市化杂志, 2012-08-21. http://www.ciudsrc.com/ne w_zazhi/fengmian/2012diqibaqihekan/2012-08-21/3 5571.html

Wang Jiazhuo,Xie Yingxia.Reason Analyse of C ousing Pluvial Flooding in China[J/OL]. URBAN IZATION, 2012-08-21. http://www.ciudsrc.com/ne W_zazhi/fengmian/2012diqibaqihekan/2012-08-21/3 5571.html

3. 仓宁. 应对城市内涝雨水规划可行的发展方向 [C].

邵益生, 新型城镇化下的工程规划探索与实 践. 北京: 中国城市出版社, 2014: 60 66

Cang Ning. A Feasible Direction to Deal with $t$ he City Waterlogging Plannin [C]. Shao Yisheng, Exploration and Practice of Engineering Plannin $\mathrm{g}$ under the New Urbanization Background. Beij ging: China City Press, 2014: 60 66

4. Maribeth Price.Mastering Arcgis[M]. LA: McGra w Hill Higher Education,2009

5. 范世香, 韩绍文. 地面坡度对地表径流影响的实 验研究[J].水土保持通报，1991，04: 6 10

Fan Shixiang,Han Shaowen.Testing Reserch on $t$ he Effects of Land Surface Slops Upon Surface Runoff[J].Bulletin of Soil and Water Conservati on, 1991, 04: 6〜10

6. 初祁, 彭定志等. 基于 MIKE11 和 MIKE 21 的城 市暴雨洪涝灾害风险分析[J]. 北京师范大学学报 (自然科学版), 2014, 05: 446 451.
Chu Qi,Peng Dingzhi,et al.Risk analysis of Urba $\mathrm{n}$ flooding by using MIKE 11 and MIKE 21[J]. JOURNAL OF BEIJING NORMAL UNIVERSI TY (NATURAL SCIENCE),2014,05: 446 451.

7. 马燕婷. 上海城市径流控制与雨洪管理的对策研 究[D].华东师范大学, 2014

Ma Yanting.Strateges to Urban Runoff Contral and Stromwater Management-a Case of Shangh ai[D].East China Normal University,2014

8. 刘敏, 权瑞松等. 城市暴雨内涝灾害风险评估: 理论、方法与实践 $[\mathrm{M}]$. 北京: 科学出版社, 201 2

Liu Ming,Quan Ruisong,et al.Risk Assessment of Urban Rainstorm Waterlogging Disaster:Theory, Method and Practice[M]. Beijing: Science Press, 2012

9. 住房和城乡建设部, 中国气象局. 城市暴雨强度 公式编制和设计暴雨雨型确定技术导则[Z]. 2014 $-04$

10. Ministry of Housing and Urban-Rural Constru ction of the PRC, China Meterological Administ ration. Technical Guidelines for Establishment of Intensity-Duration-Frequency Curve and Design Rainstorm Profile[Z]. 2014-04 